\title{
Factor X Antigen Measurement
}

National Cancer Institute

\section{Source}

National Cancer Institute. Factor X Antigen Measurement. NCI Thesaurus. Code C161824.

The determination of the amount of factor $X$ antigen present in a sample. 